\title{
Geological mapping and stand-up time estimation based on core drill evaluation using RMR89 on Tunnel 3 Sigli Banda Aceh Toll Road
}

\author{
Hanif Khoirul Latif ${ }^{1,2}$, Salahuddin Husein ${ }^{1 *}$, and I Gde Budi Indrawan ${ }^{1}$ \\ ${ }^{1}$ Gadjah Mada University, Yogyakarta, Indonesia \\ ${ }^{2}$ Regional Infrastructure Development Agency, Ministry of Public Works and Housing, Indonesia
}

\begin{abstract}
Tunnel 3 of the Sigli Banda Aceh Toll Road has been designed based on several site investigations. The site investigations have not included surface geological investigations. Subsurface geological investigations have been carried out but with less detailed drill core evaluation. This will cause less accuracy on the assessed tunnel stand-up time. This research aims to evaluate the engineering geological conditions at the tunnel construction site by conducting geological mapping with 1:5,000 scale and re-evaluating drill core using $\mathrm{RMR}_{89}$ method more thoroughly so that it can produce more accurate assessment of the tunnel stand-up time. The geological mapping result shows that the research area has three rock units, namely lapili, tuffaceous sandstones, and interbedded sandstone-siltstones, with moderate to fresh weathering degree. The drill core evaluation shows that research area has poor to good rock mass classes $(34-67)$. The drill core evaluation results also indicate possible geological structures that may influence subsurface rock mass strength. The tunnel stand-up time obtained from the lowest $\mathrm{RMR}_{89}$ value for each drill core shows a value of 5 - 90 hours, implying immediate application of support system after tunnel excavation.
\end{abstract}

\section{Introduction}

The Sigli - Banda Aceh Toll Road consists of six sections. Section one is section Seulimeum - Padang Tiji. The Seulimeum - Padang Tiji section is planned for $26 \mathrm{~km}$. The construction of the Sigli - Banda Aceh Toll Road section one, 3 tunnels included, is carried out by PT. Hutama Karya with PT. Adhi Karya as contractor and PT. Indra Karya as a planning consultant. This research is conducted in Tunnel 3 which is located at station $15+400$ to station $15+750$ with a length of $325 \mathrm{~m}$.

In the construction stage of Tunnel 3, a series of geology and geological engineering investigations have been carried out by PT. Indra Karya. The investigation consisted of topographic survey, drill core taking, geoelectrical investigation, and rock mass quality classification. The results of the investigation stated that Tunnel 3 has a type of sandstone rock with a weak compressive strength value. Meanwhile, the classification of subsurface rock mass quality on the drill core using the rock mass rating $\left(\mathrm{RMR}_{89}\right)$ [1] method illustrates that the rock mass quality is in the fair to poor class. The stand-up time obtained from the results of the rock mass quality class has a range from 3 hours to 100 hours $[2,3]$.

The various investigations that have been carried out by the planning consultant have only been carried out specifically at the location of the tunnel alignment. The investigation also has not included elements of surface geological investigations. Only subsurface investigations have been carried out. In fact, to produce sufficient knowledge regarding geological conditions and engineering geology in detail, it will not be sufficient to rely solely on subsurface aspects. Surface aspects are also needed to support subsurface findings. Investigations on the quality of rock mass using the $\mathrm{RMR}_{89}$ classification that have been carried out by the planning consultant have also not been carried out in detail. The investigation was only carried out by assessing $\mathrm{RMR}_{89}$ from the average drill core condition obtained. The $\mathrm{RMR}_{89}$ value obtained only from the average drill core condition is feared not precise enough in describing the quality conditions of the rock mass in the field so that it can cause misleading in determining the estimated stand up time of the tunnel.

Based on the lack of detailed geological and engineering geology investigations in the construction of Tunnel 3, this research seeks to provide comparative data by conducting surface geological investigations through large-scale geological mapping at the tunnel construction site. Investigation of subsurface geological conditions will also be carried out again by evaluating the drill core in detail using the $\mathrm{RMR}_{89}$ method to determine the quality of the subsurface rock mass at the research area. The calculation of the standup time will be carried out based on the results of the classification of rock mass quality using the $\mathrm{RMR}_{89}$ method.

*Corresponding author: shddin@ugm.ac.id 


\section{Methodology}

\subsection{Geological Condition}

The research area is part of Geologic Map of Banda Aceh Quadrangle by Bennet, et al, [4] with $1: 25.000$ map scale. The rock formation on research area is part of Padang Tiji Member and around the research location there are the Alluvium Formation, Lam Teuba Volcano Formation, Indrapuri Formation, Seulimeum Formation, Kotabakti Formation and Padang Tiji Members (See Fig.1).

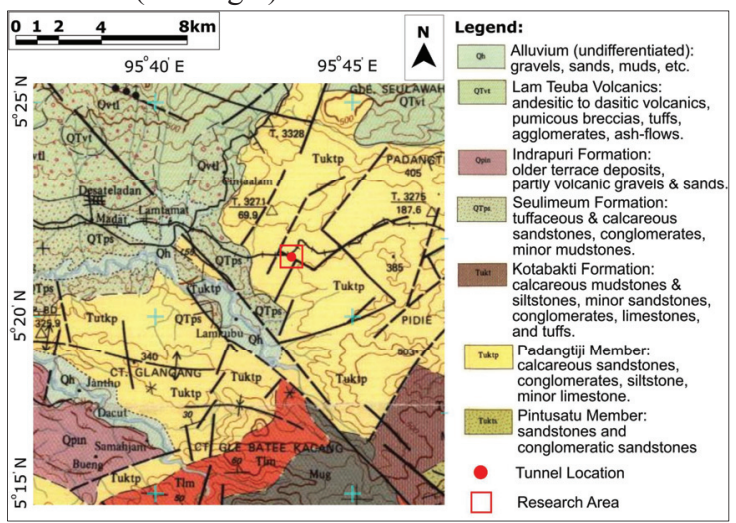

Fig. 1. Regional geological map of research area [4]

In Fig. 1, it can also be observed that there is a geological structure in the form of a fault in the research area. The fault is a branch of the Seulimeum Fault. The Seulimeum fault is an active fault that cuts through Plio - Pleistocene and volcanic sedimentary rocks from Mount Seulawah Agam [5].

\subsection{Geological Mapping}

Geological mapping is a highly interpretive scientific process by which a geological mapper seeks to understand the composition and structure of the surface and subsurface geology of the earth.

In conducting geological mapping, a geological mapper will record in a field book about geological features such as strikes and dips, rock types, weathering levels, sketches of rock outcrops and so on. The more narratives obtained in the field will make it easier for a geological mapper to compile a geological map.

In this research, geological mapping was carried out with a mapping area of $1 \times 1 \mathrm{~km}$ with a mapping time of 30 days. The geological trajectory map is made based on the contours obtained from the digital elevation model (DEM) data. The geological trajectory map covers the entire research area with 37 field observation stations.

\subsection{Rock Mass Rating}

The RMR classification $\left(\mathrm{RMR}_{89}\right)$ was first proposed by Bieniawski [1] using six parameters to determine the rock mass rating. The six parameters are uniaxial compressive strength (UCS) for intact rock, rock quality designation (RQD), discontinuity spacing, discontinuity conditions, groundwater conditions and discontinuity orientation.

Each of the six parameters has the following weightings: 0 to 15 for the strength of the intact rock material, 3 to 20 for RQD, 5 to 20 for the spacing of discontinuity, 0 to 30 for discontinuity conditions, 0 to 15 for groundwater conditions, and 0 to $(-12)$ for discontinuity effects. The maximum value of the weighting of the RMR parameter is 100 . Classes in RMR classification are divided into 5 classes from very poor to very good. In this research, RMR will be used in determining subsurface rock mass classification based on four drill core points (T35A, T35B, T36A, T36B).

The strength parameters of intact rock material based on UCS used in this study were obtained from the value of UCS test in the laboratory for four drill core points at a certain depth produced by the planning consultant (see Table 1). The depth point is selected based on the selection of samples that represent the condition of the level of rock weathering and rock strength from the drill core taken. $\mathrm{RMR}_{89}$ rating for the strength parameters of intact rock materials can be seen in Table 2 .

Table 1. UCS value of drill cores

\begin{tabular}{|c|c|c|c|}
\hline No & Core Number & Depth (m) & UCS value (Mpa) \\
\hline \multirow{6}{*}{1} & \multirow{6}{*}{$\mathrm{T} 35 \mathrm{~A}$} & $6.50-7.00$ & 0.248 \\
\hline & & $21.10-22.00$ & 10.741 \\
\hline & & $29.25-30.00$ & 1.903 \\
\hline & & $35.35-36.00$ & 10.027 \\
\hline & & $39.20-40.00$ & 7.877 \\
\hline & & $43.00-43.65$ & 1.494 \\
\hline \multirow{6}{*}{2} & \multirow{6}{*}{ T35B } & $6.10-6.60$ & 2.930 \\
\hline & & $22.40-23.00$ & 1.894 \\
\hline & & $30.30-30.90$ & 5.680 \\
\hline & & $34.40-35.00$ & 3.265 \\
\hline & & $37.20-37.80$ & 4.262 \\
\hline & & $42.40-43.00$ & 4.784 \\
\hline \multirow{6}{*}{3} & \multirow{6}{*}{ T36A } & $1.80-2.50$ & 4.403 \\
\hline & & $19.10-19.70$ & 4.045 \\
\hline & & $26.10-26.90$ & 8.589 \\
\hline & & $33.40-34.00$ & 5.571 \\
\hline & & $38.40-38.90$ & 6.347 \\
\hline & & $45.00-45.60$ & 6.985 \\
\hline \multirow{6}{*}{4} & \multirow{6}{*}{ T36B } & $6.40-6.60$ & 3.016 \\
\hline & & $9.70-9.90$ & 2.736 \\
\hline & & $12.30-12.80$ & 3.772 \\
\hline & & $14.20-14.60$ & 6.671 \\
\hline & & $17.60-18.00$ & 3.398 \\
\hline & & $22.60-22.80$ & 5.517 \\
\hline
\end{tabular}

The RQD parameter used in this study is the RQD value per one meter on each drill core. The calculation 
of the RQD value was carried out using the RQD measurement guide in Fig. 2 [6]. Meanwhile, the formula used to calculate the RQD value can be seen in formula (1) [6]. $\mathrm{RMR}_{89}$ rating for RQD parameter can be seen in Table 3 .

Table 2. UCS rating used at $\mathrm{RMR}_{89}[1]$

\begin{tabular}{cc}
\hline UCS $(\mathrm{MPa})$ & Rating \\
\hline$>250$ & 15 \\
$100-250$ & 12 \\
$50-100$ & 7 \\
$25-50$ & 4 \\
$5-25$ & 2 \\
$1-5$ & 1 \\
$<1$ & 0 \\
\hline
\end{tabular}

$$
\begin{gathered}
R Q D= \\
\frac{\text { LLength of core pieces }>10 \mathrm{~cm} \text { length }}{\text { Total length of core run }} \times 100 \%
\end{gathered}
$$

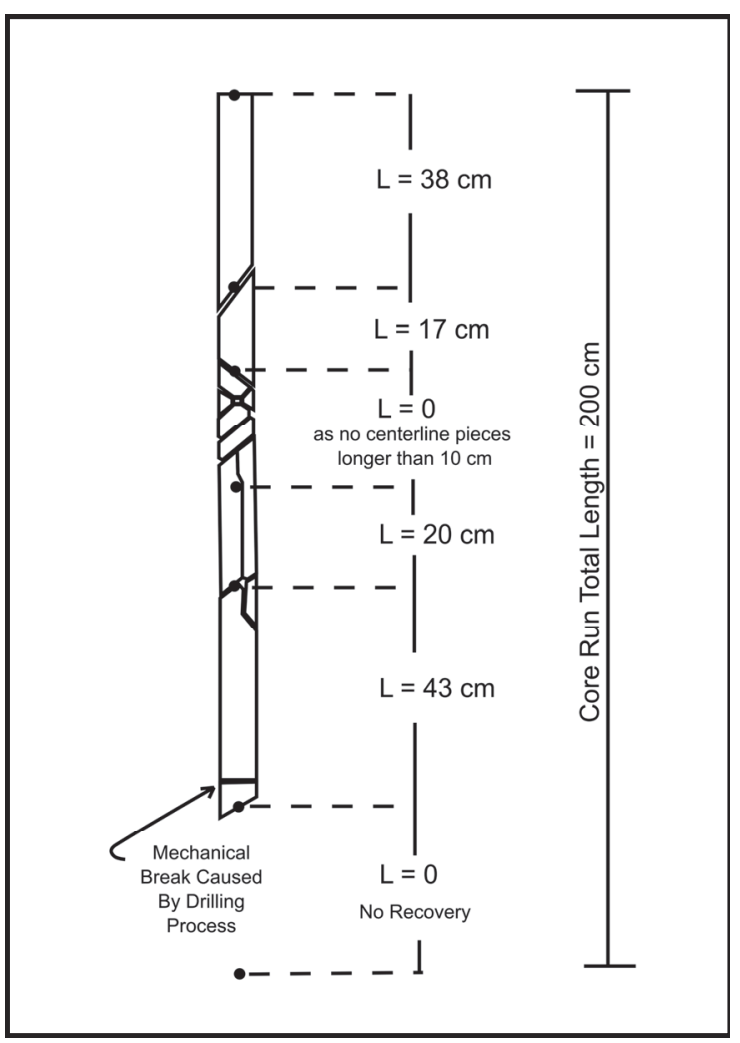

Fig. 2. RQD measurement guidance [6]

Table 3. RQD rating at RMR89 [1]

\begin{tabular}{cc}
\hline Drill core quality RQD (\%) & Rating \\
\hline $90-100$ & 20 \\
$75-90$ & 17 \\
$50-75$ & 13 \\
$25-50$ & 8 \\
$<25$ & 3 \\
\hline
\end{tabular}

The discontinuity spacing parameter used in this study was obtained from the perpendicular distance between two successive discontinuity planes (joints, faults, folds, bedding planes, etc.) along the measurement line on the drill core. Discontinuity spacing rating in $\mathrm{RMR}_{89}$ is classified based on the range of distances between discontinuities. The wider the distance between the discontinuities, the higher the rating given. This is because discontinuities with a close distance will weaken the strength of the rock mass. Discontinuity spacing rating on $\mathrm{RMR}_{89}$ can be seen in Table 4.

Table 4. Rating of discontinuity spacing used at $\mathrm{RMR}_{89}[1]$

\begin{tabular}{cc}
\hline Discontinuity spacing $(\mathrm{m})$ & Rating \\
\hline$>2$ & 20 \\
$0.6-2$ & 15 \\
$0.2-0.6$ & 10 \\
$0.006-0.2$ & 8 \\
$<0.006$ & 5 \\
\hline
\end{tabular}

The discontinuity condition parameter used in this study has five sub-parameters, namely persistence, separation, roughness, infilling and the level of weathering of the discontinuity plane. Persistence is the length of the discontinuity plane. Separation is the distance between the discontinuity plane faces. Roughness is the roughness of the discontinuity face. The rougher the discontinuity planes, the more likely they are to interlock. Infilling is a material that fills the discontinuity plane. The material can be hard or soft material. The hardness or softness of the filler material will have a different value in the $\mathrm{RMR}_{89}$ rating. Weathering level is the degree of weathering conditions of discontinuities in rock. Ratings for each sub-parameter in the discontinuity condition parameters can be seen in Table 5 .

Table 5. $\mathrm{RMR}_{89}$ rating of sub-parameters of discontinutity condition [1]

\begin{tabular}{cccccc}
\hline Parameter & \multicolumn{5}{c}{ Ratings } \\
\hline $\begin{array}{c}\text { Presistence } \\
(\mathrm{m})\end{array}$ & $<1$ & $1-3$ & $3-10$ & $10-20$ & $>20$ \\
& 6 & 4 & 2 & 1 & 0 \\
$\begin{array}{c}\text { Separation } \\
(\mathrm{mm})\end{array}$ & None & $<0.1$ & $0.1-$ & $1-5$ & $>5$ \\
& 6 & 5 & 4 & 1 & 0 \\
Roughness & Very & Rough & Slight & Smooth & $\begin{array}{c}\text { Slicken } \\
\text { sided }\end{array}$ \\
& 6 & 5 & 3 & 1 & 0 \\
$\begin{array}{c}\text { Infilling } \\
(\mathrm{mm})\end{array}$ & None & $<5$ & $>5$ & $<5$ & $>5$ \\
& 6 & 4 & 2 & 2 & 0 \\
& None & Slight & Moderate & High & $\begin{array}{c}\text { Decom } \\
\text { posed }\end{array}$ \\
Weathering & 6 & 5 & 3 & 1 & 0 \\
\hline
\end{tabular}

The groundwater condition parameters used in this study were obtained from rubbing the surface of the drill core with the palm of the hand. In addition, the assessment of this parameter is also carried out by 
taking into account the assessment of the planning consultant on the parameters of the groundwater condition of the drill core. There are several ground water conditions, namely completely dry, damp, wet, dripping, and flowing. The rating of groundwater conditions at $\mathrm{RMR}_{89}$ can be seen in Table 6 .

Table 6. Rating of groundwater condition at $\mathrm{RMR}_{89}[1]$

\begin{tabular}{cc}
\hline $\begin{array}{c}\text { Groundwater } \\
\text { (general condition) }\end{array}$ \\
\hline Condition & Rating \\
Complitely dry & 15 \\
Damp & 10 \\
Wet & 7 \\
Dripping & 4 \\
Flowing & 0 \\
\hline
\end{tabular}

The discontinuity plane orientation parameter is represented by strike and dip. The orientation of the discontinuity plane is categorized in terms of favourable and unfavourable (see Table 7). Ratings for discontinuity orientation can be seen in Table 8 .

Table 7. Category of discontinuity plane orientation [1]

Strike Perpendicular to Tunnel Axis

Drive with Dip

\begin{tabular}{|c|c|c|c|}
\hline $\begin{array}{c}\operatorname{Dip} 45^{\circ}- \\
90^{\circ}\end{array}$ & Dip $20^{\circ}-45^{\circ}$ & $\begin{array}{c}\operatorname{Dip} 45^{\circ}- \\
90^{\circ}\end{array}$ & $\begin{array}{c}\operatorname{Dip} 20^{\circ}- \\
45^{\circ}\end{array}$ \\
\hline $\begin{array}{c}\text { Very } \\
\text { favorable }\end{array}$ & Favorable & Fair & $\begin{array}{c}\text { Unfavorab } \\
\text { le }\end{array}$ \\
\hline
\end{tabular}

Strike Parallel to Tubbel Axis Irrespective of Strike

$\begin{array}{ccc}\begin{array}{c}\text { Dip } 20^{\circ}- \\ 45^{\circ}\end{array} & \text { Dip } 45^{\circ}-90^{\circ} & \text { Dip } 0^{\circ}-20^{\circ} \\ \text { Fair } & \begin{array}{c}\text { Very } \\ \text { unfavorable }\end{array} & \text { Fair }\end{array}$

Table 8. $\mathrm{RMR}_{89}$ ratings for discontinuity plane orientation [1]

Ratings of Discontinuity Plane Orientation for Tunnels

\begin{tabular}{cc} 
Descriptions & Ratings \\
Very favorable & 0 \\
Favorable & -2 \\
Fair & -5 \\
Unfavorable & -10 \\
Very unfavorable & -12 \\
\hline
\end{tabular}

\subsection{Stand Up Time}

The term stand-up time was first used by Lauffer [7] in Lauffer's rock mass classification and then further developed by Lauffer [8] for excavation using tunnel boring machines purpose. Stand-up time is defined as the length of time the tunnel can support itself without additional supporting structures [9]. The stand-up time estimation is very important because it will affect the excavation cycle, the required support structure, and the tunnel excavation method.

The stand-up time developed by Lauffer is then correlated with rock mass classification and the most frequently applied in tunnel construction work is the RMR and stand-up time correlation by Bieniawski [1]. The correlation by Bieniawski can be seen in Fig. 3 .

In this research, the correlation between stand up time and RMR by Bieniawski is used to determine the stand-up time estimation. The RMR value used to correlate with stand-up time is the lowest RMR value of each drill core point at the tunnel elevation $(30 \mathrm{~m})$.

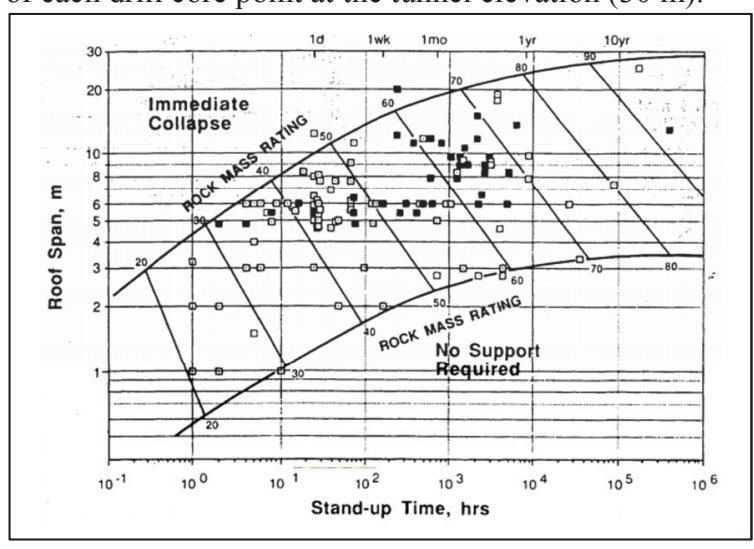

Fig. 3. Stand-up time and RMR value relation [1]

\section{Result and Discussion}

Based on the geological mapping carried out in the research area, it was found that the research area has three rock units, namely lapili, tuffaceous sandstones, and interbedded sandstone-siltstones (see Fig 4, 5 and $6)$.

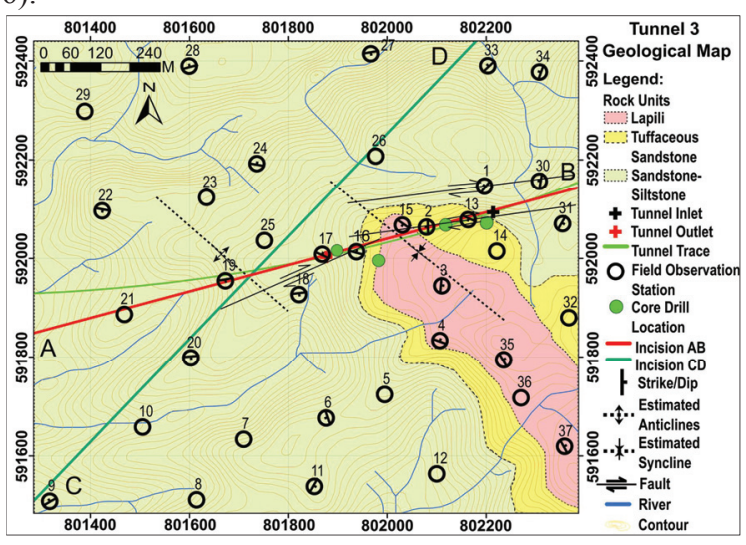

Fig. 4. Geological map of Tunnel 3

Lapili have a moderate level of weathering, tuffaceous sandstones have a moderate to slight level of weathering, while sandstone-siltstones have a slight to fresh level of weathering. The rock type and weathering level have a good correlation with the observations on the drill core. The results of observations of rock types in the drill core state that the research area consists of two rock units, namely tuffaceous sandstone and interbedded sandstone- 
siltstone. Lapilli were not found in the drill core because the drill core extraction areas were not in the lapilli zone as shown in Fig. 4. From observations on the drill core it was also found that the rocks in the study area experienced moderate to fresh weathering degrees (see Table 9).

Table 9. Lithology and degree of weathering based on drill core evaluation

\begin{tabular}{|c|c|c|c|c|}
\hline No & Core & $\begin{array}{l}\text { Depth } \\
\text { (m) }\end{array}$ & Rock Unit & $\begin{array}{c}\text { Weathering } \\
\text { Level }\end{array}$ \\
\hline \multirow{3}{*}{1} & \multirow{3}{*}{ T36B } & $0-15$ & $\begin{array}{l}\text { Interbedded } \\
\text { Sandstone- } \\
\text { Siltstone }\end{array}$ & $\begin{array}{c}\text { Slightly } \\
\text { Weathered }\end{array}$ \\
\hline & & & & \\
\hline & & $15-30$ & $\begin{array}{l}\text { Interbedded } \\
\text { Sandstone- } \\
\text { Siltstone }\end{array}$ & Fresh \\
\hline \multirow{5}{*}{2} & \multirow{5}{*}{$\mathrm{T} 35 \mathrm{~A}$} & $0-10$ & $\begin{array}{l}\text { Tuffaceous } \\
\text { Sandstone }\end{array}$ & $\begin{array}{l}\text { Moderately } \\
\text { weathered }\end{array}$ \\
\hline & & $10-29$ & $\begin{array}{l}\text { Tuffaceous } \\
\text { Sandstone }\end{array}$ & $\begin{array}{c}\text { Slightly } \\
\text { Weathered }\end{array}$ \\
\hline & & & & \\
\hline & & $29-40$ & $\begin{array}{l}\text { Interbedded } \\
\text { Sandstone- } \\
\text { Siltstone }\end{array}$ & $\begin{array}{c}\text { Slightly } \\
\text { Weathered }\end{array}$ \\
\hline & & $40-51$ & $\begin{array}{l}\text { Interbedded } \\
\text { Sandstone- } \\
\text { Siltstone }\end{array}$ & Fresh \\
\hline \multirow{3}{*}{3} & \multirow{3}{*}{ T $35 \mathrm{~B}$} & $0-31$ & $\begin{array}{l}\text { Tuffaceous } \\
\text { Sandstone }\end{array}$ & $\begin{array}{c}\text { Moderately } \\
\text { weathered }\end{array}$ \\
\hline & & $31-46$ & $\begin{array}{l}\text { Interbedded } \\
\text { Sandstone- } \\
\text { Siltstone }\end{array}$ & $\begin{array}{c}\text { Slightly } \\
\text { Weathered }\end{array}$ \\
\hline & & $46-49$ & $\begin{array}{l}\text { Interbedded } \\
\text { Sandstone- } \\
\text { Siltstone }\end{array}$ & Fresh \\
\hline \multirow{3}{*}{4} & \multirow{3}{*}{ T $36 \mathrm{~A}$} & $0-22$ & $\begin{array}{l}\text { Tuffaceous } \\
\text { Sandstone }\end{array}$ & $\begin{array}{c}\text { Moderately } \\
\text { weathered }\end{array}$ \\
\hline & & $22-34$ & $\begin{array}{l}\text { Interbedded } \\
\text { Sandstone- } \\
\text { Siltstone }\end{array}$ & $\begin{array}{c}\text { Slightly } \\
\text { Weathered }\end{array}$ \\
\hline & & $34-56$ & $\begin{array}{l}\text { Interbedded } \\
\text { Sandstone- } \\
\text { Siltstone }\end{array}$ & Fresh \\
\hline
\end{tabular}

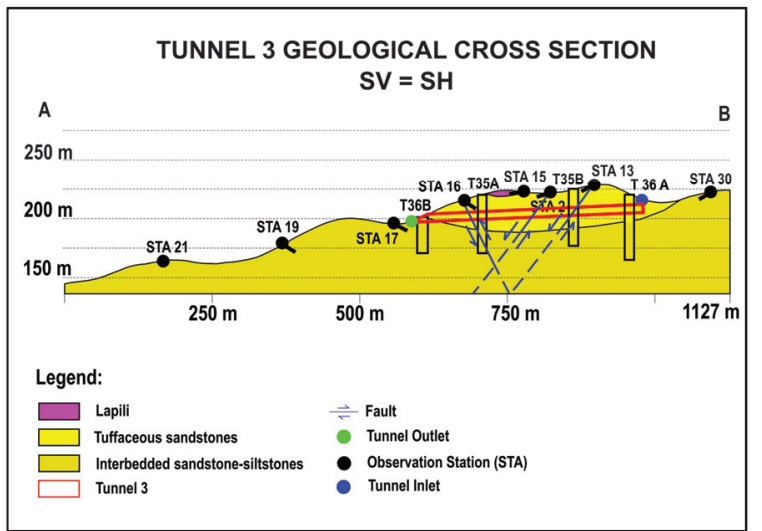

Fig. 5. Geological cross section $A B$

From the geological mapping carried out, it was also found that there were several geological structures such as folds and faults. These faults are faults found in STA 2, STA 13, and STA 16. These faults intersect the tunnel path as shown in Fig. 5. In Fig. 5, it can be seen that the direction of the fault dip is not only cutting the tunnel line but also cutting the drill core bits T35A and T35B.

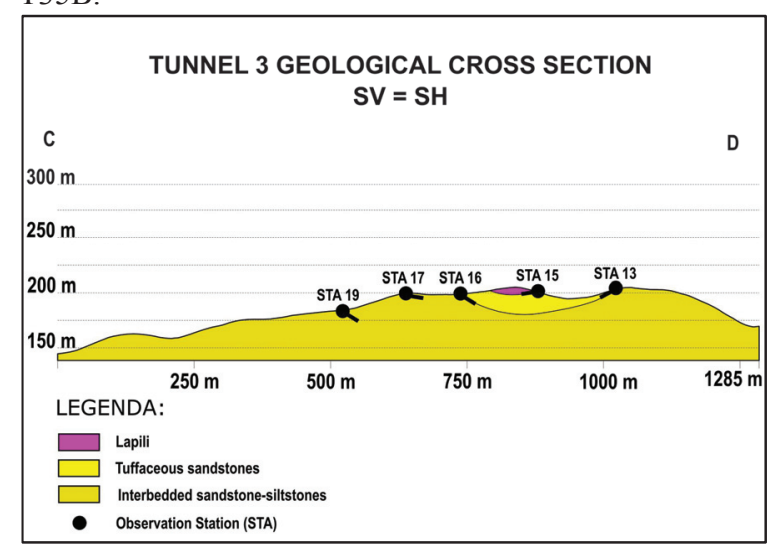

Fig. 6. Geological cross section CD

The results obtained from the subsurface rock mass classification using $\mathrm{RMR}_{89}$ as shown in the table 10 indicate that the research area has a rock mass between 34 to 67 . The rock mass value indicates that the quality of the subsurface rock mass in the study area consists of tuffaceous sandstone with poor to good quality, and sandstones from poor to good quality. The variation in the quality of the rock mass is possible because of the geological structure in the form of faults as discussed in the previous paragraph. In the T35A drill core, there was a decrease in rock mass quality at a depth of $40 \mathrm{~m}$ $51 \mathrm{~m}$ where there was an intersection with the fault. The same thing also happened to the T35B drill core which experienced a decrease in rock mass quality at a depth of $7 \mathrm{~m}-13 \mathrm{~m}$.

The results of subsurface rock mass rating using the RMR method are then used as the basis for calculating the stand-up time by taking the lowest RMR rating of each drill cores at the tunnel elevation $(30 \mathrm{~m})$. The lowest rating is correlated using the stand up time chart developed by Bieniawski [1]. The roof span required 
for correlation is obtained from the tunnel planning roof span of $10 \mathrm{~m}$. The correlation results illustrate that Tunnel 3 of Sigli Banda Aceh Toll Road according to the drill core T35A has a stand-up time of 90 hours, according to drill core T35B 10 hours, according to drill core T36A 90 hours, and according to drill core T36B 5 hours. More detail regarding the stand-up time for Tunnel 3 of Sigli Banda Aceh Toll Road can be seen in Fig. 7, Fig. 8, Fig. 9, and Fig. 10.

Table 10. Rock mass quality on research area

\begin{tabular}{|c|c|c|c|c|}
\hline Core & $\begin{array}{c}\text { Depth } \\
\text { (m) }\end{array}$ & Lithology & $\begin{array}{c}\text { RMR89 } \\
\text { Rating }\end{array}$ & $\begin{array}{l}\text { RMR89 } \\
\text { Quality }\end{array}$ \\
\hline \multirow{3}{*}{ T36B } & $0-9$ & $\begin{array}{l}\text { Interbedded } \\
\text { Sandstone- } \\
\text { Siltstone }\end{array}$ & $34-44$ & $\begin{array}{l}\text { Poor to } \\
\text { Fair }\end{array}$ \\
\hline & $9-14$ & $\begin{array}{l}\text { Interbedded } \\
\text { Sandstone- } \\
\text { Siltstone }\end{array}$ & $44-51$ & Fair \\
\hline & $14-30$ & $\begin{array}{l}\text { Interbedded } \\
\text { Sandstone- } \\
\text { Siltstone }\end{array}$ & $36-45$ & Fair \\
\hline \multirow{4}{*}{$\mathrm{T} 35 \mathrm{~A}$} & $0-15$ & $\begin{array}{l}\text { Tuffaceous } \\
\text { Sandstone }\end{array}$ & $42-58$ & Fair \\
\hline & $15-29$ & $\begin{array}{l}\text { Tuffaceous } \\
\text { Sandstone }\end{array}$ & $55-67$ & $\begin{array}{c}\text { Fair to } \\
\text { Good }\end{array}$ \\
\hline & $29-40$ & $\begin{array}{l}\text { Interbedded } \\
\text { Sandstone- } \\
\text { Siltstone }\end{array}$ & $55-66$ & $\begin{array}{c}\text { Fair to } \\
\text { Good }\end{array}$ \\
\hline & $40-51$ & $\begin{array}{l}\text { Interbedded } \\
\text { Sandstone- } \\
\text { Siltstone }\end{array}$ & $45-55$ & Fair \\
\hline \multirow{7}{*}{ T35B } & $0-7$ & $\begin{array}{l}\text { Tuffaceous } \\
\text { Sandstone }\end{array}$ & $42-54$ & Fair \\
\hline & $7-13$ & $\begin{array}{l}\text { Tuffaceous } \\
\text { Sandstone }\end{array}$ & $37-42$ & $\begin{array}{l}\text { Poor to } \\
\text { Fair }\end{array}$ \\
\hline & $13-17$ & $\begin{array}{l}\text { Tuffaceous } \\
\text { Sandstone }\end{array}$ & $42-51$ & Fair \\
\hline & $17-25$ & $\begin{array}{l}\text { Tuffaceous } \\
\text { Sandstone }\end{array}$ & $37-47$ & $\begin{array}{l}\text { Poor to } \\
\text { Fair }\end{array}$ \\
\hline & $25-31$ & $\begin{array}{l}\text { Tuffaceous } \\
\text { Sandstone }\end{array}$ & $42-57$ & Fair \\
\hline & $31-45$ & $\begin{array}{l}\text { Interbedded } \\
\text { Sandstone- } \\
\text { Siltstone }\end{array}$ & $44-61$ & $\begin{array}{c}\text { Fair to } \\
\text { Good }\end{array}$ \\
\hline & $45-49$ & $\begin{array}{l}\text { Interbedded } \\
\text { Sandstone- } \\
\text { Siltstone }\end{array}$ & $39-54$ & $\begin{array}{l}\text { Poor to } \\
\text { Fair }\end{array}$ \\
\hline \multirow{5}{*}{ T36A } & $0-22$ & $\begin{array}{l}\text { Tuffaceous } \\
\text { Sandstone }\end{array}$ & $42-59$ & Fair \\
\hline & $22-28$ & $\begin{array}{l}\text { Interbedded } \\
\text { Sandstone- } \\
\text { Siltstone }\end{array}$ & $50-55$ & Fair \\
\hline & $28-35$ & $\begin{array}{l}\text { Interbedded } \\
\text { Sandstone- } \\
\text { Siltstone }\end{array}$ & $55-62$ & $\begin{array}{l}\text { Fair to } \\
\text { Good }\end{array}$ \\
\hline & $35-50$ & $\begin{array}{l}\text { Interbedded } \\
\text { Sandstone- } \\
\text { Siltstone }\end{array}$ & 63 & Good \\
\hline & $50-56$ & $\begin{array}{l}\text { Interbedded } \\
\text { Sandstone- } \\
\text { Siltstone }\end{array}$ & $51-63$ & $\begin{array}{c}\text { Fair to } \\
\text { Good }\end{array}$ \\
\hline
\end{tabular}

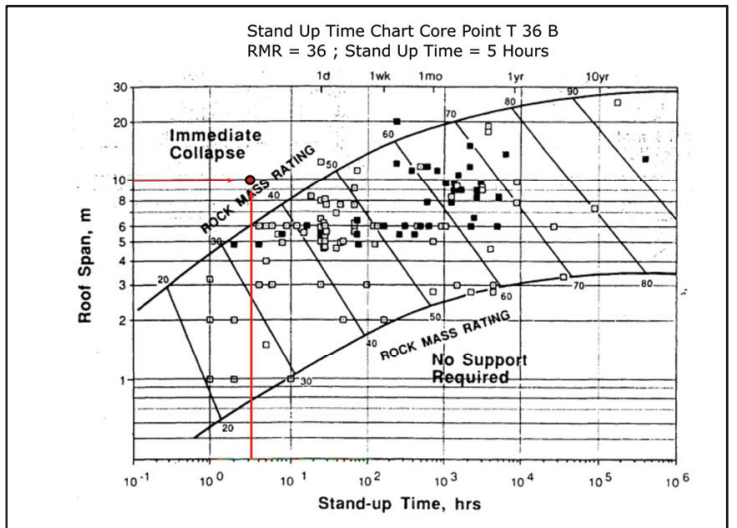

Fig. 7. Stand-up time based on lowest RMR on T36B

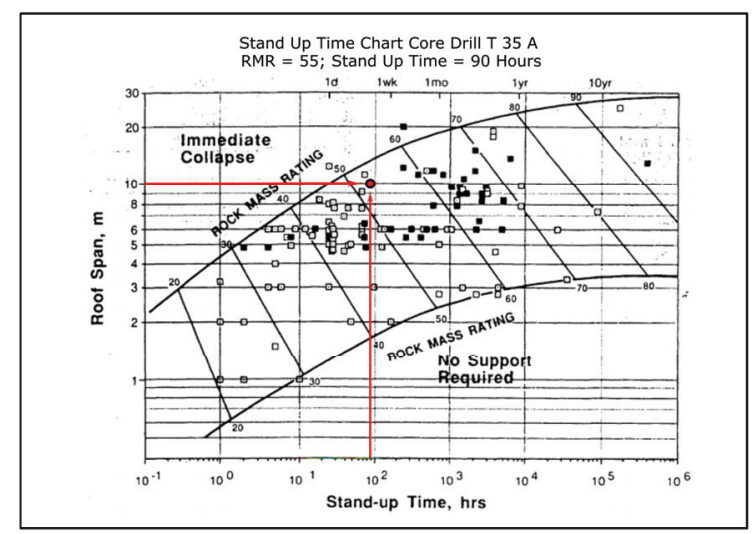

Fig. 8. Stand-up time based on lowest RMR on T35A

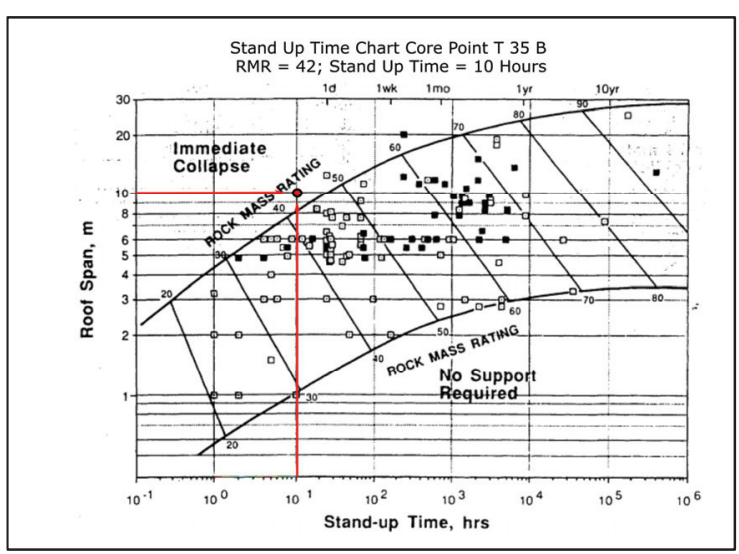

Fig. 9. Stand-up time based on lowest RMR on T35B 


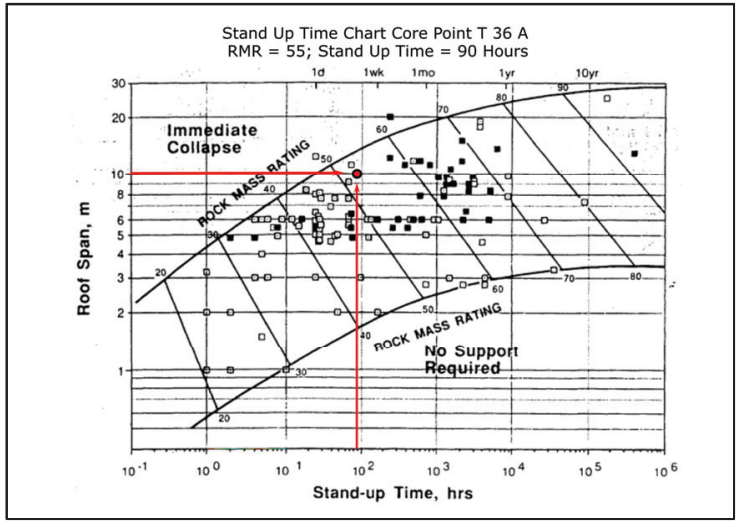

Fig. 10. Stand-up time based on lowest RMR on T36A

\section{Conclusion}

Based on geological mapping, the research area has three rock units, namely lapilli, tuffaceous sandstone, and interbedded sandstone-siltstone. Lapilli has a moderate level of weathering, tuffaceous sandstone has a moderate to slight weathering level, while the interbedded sandstone-siltstone has a slight to fresh weathering level. The results of the geological mapping have a correlation with the results of drill core evaluations on the type of rock unit and the level of weathering. From the type of rock unit and the level of weathering, it can be seen that there is no rock with a high level of weathering. This can be considered in the planning of tunnel excavation method.

Evaluation of subsurface rock mass quality using $\mathrm{RMR}_{89}$ method shows the level of strength from poor to good with a rating range of $34-67$. The results of the subsurface rock mass quality classification indicate the possibility of geological structure influence on the quality of rock mass. It is indicated with a decrease in quality at a certain depth that intersects with a geological structure in the form of faults. Evaluation of the quality of the subsurface rock mass supported by geological mapping is expected to be more accurate data in determining tunnel stand-up time.

The lowest $\mathrm{RMR}_{89}$ value in the study area for each drill core used to determine stand up time shows Tunnel 3 on the Sigli - Banda Aceh Toll Road can survive without reinforcement for 5 to 90 hours. According to the result, it is necessary to immediately strengthen the tunnel during the excavation process to avoid collapse and construction failure.

Further research is needed including determining the excavation method and tunnel stability analysis based on the $\mathrm{RMR}_{89}$ value and stand up time data that have been obtained.

\section{Acknowledgments}

The authors greatfully acknowledge to the Ministry of Public Works and Public Housing for the full support of research funding through the 2020 Superspecialist scholarship program at the Geological Engineering
Studies of Tunnel and Underground Space, Master Program of Geological Engineering, Gadjah Mada University, and to PT. Hutama Karya (Persero) and also PT. Adhi Karya (Persero) for the availability of data and convenience during data collection.

\section{References}

1. Z. T. Bieniawski, Engineering Rock Mass Classifications: A Complete Manual for Engineers and Geologists in Mining, Civil and Petroleum Engineering. New York (1989)

2. PT. Adhi Karya (Persero) Tbk. and PT. Indra Karya (Persero), Final Report Pekerjaan Penyelidikan Geologi Jalur Terowongan Seksi 1 Proyek Pembangunan Jalan Tol Trans Sumatera Ruas Sigli - Banda Aceh. Unpublished (2020)

3. PT. Indra Karya (Persero), Hasil Studi Kelayakan Terowongan Jalan Tol Ruas Sigli-Banda Aceh Proyek Pembangunan Jalan Tol Trans Sumatera Ruas Sigli-Banda Aceh Seksi 1. Unpublished (2020)

4. J.D. Bennet, D.McC. Bridge, N.R. Cameron, A. Djunuddin, S.A. Ghazali, D.H. Jeffery, W. Kartawa, W. Keats, N.M.S. Rock, S.J. Thomson, R. Whandoyo, Peta Geologi Lembar Banda Aeh, Sumatra (1981)

5. A.J. Barber, M.J. Crow, J.S. Milsom, Sumatera: Geology, Resources and Tectonic Evolution. London (2005)

6. D. U. Deere and D. W. Deere, The rock quality. des., J. Rock Class. Syst. for Eng. Purposes, 91101 (1988)

7. H. Lauffer, Gebirgsklassifizierung fur, J. Geologic und Bauwesan, 24, 46-51 (1958).

8. H. Lauffer, Zur gebirgs., J. Felsbau, 6, 137-149 (1988)

9. V. M. Nguyen and Q. P. Nguyen, Analytical sol., J. Tunn. Undergr. Sp. Technol., 47, 10-15 (2015) 